\title{
ТЕХНОЛОГІЯ НАТУРАЛЬНОГО КОСМЕТИЧНОГО ТОНІКА НА ОСНОВІ ВОДНОГО ЕКСТРАКТУ З М’ЯТКИ ЯДРА АБРИКОСОВИХ КІСТОЧОК
}

\author{
${ }^{1}$ Котляр Є.О., канд. техн. наук, доцент, ${ }^{1}$ Ткаченко Н.А., д-р техн. наук, професор, \\ ${ }^{1}$ Вікуль С.І., канд. техн. наук, доцент, ${ }^{2}$ Левчук І.В., Д-р техн. наук, ст. наук. співробітник \\ ${ }^{1}$ Одеська національна академія харчових технологій, м. Одеса \\ 2 ДП «УКРМЕТРТЕСТСТАНДАРТ», м. Київ
}

\begin{abstract}
Анотація. В останні роки фармацевтична, косметична $i$ харчова промисловості виявляють зростаючий інтерес до використання природних антиоксидантів, отриманих з плодово-ягідних рослин. Аналіз хімічного складу різних фруктів та ягід, які вирощують в Украӥні, та дані їх використання у різних галузях промисловості, дозволяють зробити висновок - перспективною сировиною для досліджень є абрикосова кісточка, а саме ядро, яке знаходиться в ній. Екстракти м'ятки ядра абрикосових кісточок можуть використовуватись для отримання препаратів біологічно активних речовин.

У роботі запропонована технологічна схема отримання водного, спиртового та водно-спиртового екстрактів із м'ятки ядра абрикосових кісточок. Отримані за иією технологією екстракти на основі м'ятки ядра абрикосових кісточок мають високу біологічну активність, що обумовлено наявністю у їх складі водорозчинних біологічно-активних речовин, які володіють антиоксидантними властивостями.

Дослідження біологічної активності водного, спиртового та водно-спиртового екстрактів на основі м'ятки ядра абрикосових кісточок свідчать, щзо водний екстракт характеризується найвищим значенням даного показника, тому саме на його основі розроблена рецептура та удосконалена технологічна схема косметичного тоніка для шкіри обличчя.

Вироблений за розробленою технологією натуральний косметичний тонік відповідає вимогам ДСТУ 4093-2002. Він має стабільну структуру, приємний колір та аромат ефірної олії. Показник рН знаходиться у нормі (межі - від 3,5 до 8,0).

Встановлено, щзо натуральний косметичний тонік для обличчя на основі водного екстракту з м'ятки абрикосового ядра біологічно активний, оскільки швидкість перенесення електрона в системі $\mathrm{NAD} \cdot \mathrm{H}_{2}-\mathrm{K}_{3} \mathrm{Fe}(\mathrm{CN})_{6}$ збільшується у його присутності. Дію розробленого натурального косметичного тоніка було перевірено за участі 20 респодентів-добровольиів. Усі вони відмітили приємний аромат продукту, значне пом'якшення шкіри обличчя після нанесення засобу (а респонденти із сухою шкірою ще й зволоження шкіри), відчуття очищення та тонізування шкіри. У жодної людини тонік не викликав алергічних реакиій.

Максимальний термін зберігання розробленого тоніка складає 30 діб за температури $(20 \pm 1){ }^{\circ} \mathrm{C}$.

Ключові слова: косметичний тонік, м'ятка ядра абрикосових кісточок, водний екстракт, біологічна активність, природний антиоксидант, технологія, рецептура.
\end{abstract}

\section{TECHNOLOGY OF A NATURAL SKIN TONER BASED ON AQUEOUS EXTRACT FROM CRUSHED APRICOT KERNELS \\ ${ }^{1}$ E. Kotlyar, Ph.D., Associate Professor, ${ }^{1}$ N. Tkachenko, Dr. Sci. Tech, Professor, ${ }^{1}$ S. VIkul, Ph.D., Associate Professor, ${ }^{2}$ I. Levchuk, Dr. Sci. Tech, Senior Researcher \\ ${ }^{1}$ Odessa National Academy of Food Technologies, Odesa ${ }^{2} \mathrm{DP}$ «UKRMETRTESTSTANDART», m. Kiev}

\begin{abstract}
In recent years, the pharmaceutical, cosmetic, and food industries have been paying more and more attention to using natural antioxidants obtained from fruit and berries. Analysis of those grown in Ukraine and data on how they are used in different branches of production allow concluding that a promising raw material for further study is the apricot stone - the kernel within it to be exact. Extracts from crushed apricot kernels can be used to produce preparations of bioactive substances.

In this research, a technology is suggested which allows obtaining aqueous, alcoholic, and hydroalcoholic extracts from crushed apricot kernels. These extracts are highly bioactive, as they contain water-soluble
\end{abstract}


bioactive substances with antioxidant properties.

The aqueous, alcoholic, and hydroalcoholic extracts from crushed apricot kernels have been studied for their bioactivity. The aqueous extract has appeared to be the most bioactive, so it has become the basis for developing the formulation of a face toner and improving the process flow of its manufacture.

The natural toner made according to the technology developed meets State Standard of Ukraine (DSTU) 4093-2002. Its structure is steady, its colour pleases the eye, and it has fragrance of essential oil. The pH is within the standard limits (3.5 to 8.0).

It has been established that the natural face toner based on aqueous extract from crushed apricot kernels is bioactive, because the electron transfer rate in the system $\mathrm{NAD} \cdot \mathrm{H}_{2}-\mathrm{K}_{3} \mathrm{Fe}(\mathrm{CN})_{6}$. increases in its presence. Twenty respondents volunteered to test the action of the newly-developed cosmetic product. All of them, besides appreciating its pleasant fragrance, noted that applying the product resulted in a significant skin-softening effect (moisturising, too, in those with a dry skin), and caused a sensation of their skin cleansed and toned. No respondent showed an allergic reaction to the toner.

The maximum shelf life of the toner developed is 30 days (at $20 \pm 1{ }^{\circ} \mathrm{C}$ ).

Key words: skin toner, crushed apricot kernels, aqueous extract, bioactivity, natural antioxidant, technology, formulation.

Абрикосові кісточки $є$ вторинною сировиною плодово-ягідної промисловості. Їх відокремлюють від решти маси, сушать і подрібнюють, щоб зруйнувати тверду оболонку - шкаралупу. Потім подрібнюють безпосередньо самі ядра з абрикосових кісточок та переходять до отримання олії. Після вилучення олії пресуванням залишається макуха, яка містить $5 . .7 \%$ жиру та білкових речовин.

Із подрібнених ядер абрикосових кісточок (м'ятки) вилучають екстракти, які потім використовують у косметичній промисловості. Наприклад, доцільним є використання цих екстрактів у тоніках для очищення і тонізування шкіри обличчя з метою відновлення кислотно-лужного балансу та нейтралізації негативного вливу жорсткої хлорованої води.

Багато харчових відходів, таких як абрикосові кісточки, що $є$ вторинною сировиною плодово-ягідної промисловості, можуть служити джерелом потенційно цінних біоактивних сполук, зокрема антиоксидантів і вітамінів, зі зростаючим науковим інтересом завдяки ї позитивному впливу на здоров'я людини [1].

Екстракти біологічно активних компонентів з рослинної сировини $є$ частиною фармацевтичної $\mathrm{i}$ харчової промисловості. В даний час для приготування екстракту рослинної олії використовується широкий спектр методів екстрагування, найчастіше це екстрагування мацерацією. Цей відносно простий метод має деякі недоліки, такі як тривалий час екстрагування, нагрівання системи і можлива деградація біологічно активних сполук, погані гідродинамічні умови для екстрагування, повільний масообмін і низький вихід, селективний витяг неполярних сполук, низький коефіцієнт використання рослинної сировини [2].

Застосування олій і рослинних олійних екстрактів у медицині бере свій початок у давній історії Єгипту, Індії, Китаю. Фармакологічна дія рослинних олій і олійних екстрактів унікальна завдяки їх здатності допомагати організму використовувати нерозкриті власні ресурси [2].

В останні роки фармацевтична, косметична і харчова промисловості виявляють зростаючий інтерес до використання природних антиоксидантів (несинтетичного походження), отриманих 3 рослин, мікроводоростів i мікроорганізмів [3]. Щорічні темпи зростання виготовлення фармацевтичних препаратів, одержаних шляхом екстрагування промислової продукції, становлять від 6 до 8 \%. Сегмент натуральної косметики також демонструє помітне зростання [3].

У сучасних умовах в усьому світі найкращою косметикою визнані натуральні й органічні косметичні засоби. Учені з різних країн прогнозували зростання попиту на натуральну косметику на початку XXI століття. Сьогодні можна стверджувати, що їх прогнози підтвердилися. Фахівці косметичної галузі констатують щорічне підвищення зацікавленості споживачів натуральними косметичними засобами. За сучасними прогнозами аналітиків, вже через пару десятків років кожна середньостатистична сім'я буде витрачати на натуральну косметику майже $15 \%$ свого бюджету [4]. Тому пошук новітніх інгредієнтів для виробництва натуральних $\mathrm{i}$ органічних косметичних засобів на основі вітчизняної сировини $\epsilon$ актуальним завданням сьогодення.

Закордоні дослідження свідчать про різноманітні фармакологічні ефекти абрикоси та ії ядра, яке включає антипаразитарні, протиракові, противікові, антиатеросклеротичні, антиангінальні, кардіопротекторні, гепатопротекторні, ренопротекторні та антиоксидантні (особливо $\beta$-каротин) властивості. Плоди абрикоси багаті корисними мінералами, особливо К, Fe, Mg i Р. Абрикоса - джерело вітамінів А, С і Е та клітковини. Вона володіє седативними, спазмолітичними, антицестодальними, антимікробними, антимутагенними, протикашльовими, протизапальними та тонізуючими ефектами [5-9]. 
У дослідженнях [10] автори повідомили, що флавоноїди, такі як кверцетин-3-рутинозид, кверцетин3-галактозид і кверцетин-3-глюкозид, є головними компонентами в абрикосі, а олія з абрикосових ядер спричинила поліпшення антиоксидантного стану печінки щурів порівняно з соняшниковою олією [10].

Олія з абрикосових кісточок має зволожувальну і пом'якшувальну дію, що дуже важливо для догляду за шкірою. Вона не викликає алергічних реакцій, не токсична, чудово розподіляється по поверхні шкіри. Завдяки своїм властивостям і делікатному впливу на шкіру їі здавна використовують для догляду за ніжною шкірою немовлят. При сухій шкірі їі можна змішувати з іншими базовими оліями у співвідношенні 1:1. Це зволожує, живить і регенерує шкіру, здійснює потужний антиоксидантний ефект. Завдяки цінним властивостям олії з абрикосових кісточок підвищується пружність шкіри, відновлюється iï еластичність і свіжість, підсилюється здатність шкіри до регенерації. Олія 3 абрикосових кісточок унікальна, багата мінералами і вітамінами. Вітамін А заспокоює шкіру, здатний нормалізувати вироблення шкірного сала, позитивно впливає на шкіру, схильну до появи висипів, покращує гостроту зору. Вітаміни групи В - допомагають поліпшити колір обличчя, а також захищають шкіру від різноманітних зовнішніх впливів. Вітамін С - найпотужніший антиоксидант та стимулятор вироблення природного коллагену. Вітамін $\mathrm{F}$ представлений в олії з абрикосових кісточок у активній формі, якщо порівнювати з подібними рослинними оліями. За його участі відбувається жировий і кисневий клітинний обміни. Також він заспокоює шкіру, попереджує лущення і сухість, захищає від променів сонця і впливу побутової хімії. Незамінний цей вітамін і для волосся та шкіри голови. Він позбавляє від неприємного відчуття стягнутості і здатний запобігти появі лупи [11], сприяє регенерації слизових оболонок.

Для тих, хто страждає на анемію, олія з абрикосових кісточок має стати постійним супутником життя завдяки великій кількості заліза, кобальту і міді, які необхідні для кровотворення. А високий вміст калію сприяє виведенню з організму надмірної кількості води, усуваючи набряки навколо очей; приймає участь у профілактиці різних захворювань нирок, серцево-судинної системи, шлунково-кишкового тракту, нервової системи, щитоподібної залози; сприяє лікуванню кашлю, гикавки, стресів, цукрового діабету, запорів, гастриту, гіповітамінозу, алергії, рахіту [12].

Розглядаючи перспективи розширення сировинної бази, необхідно звернути увагу на проблему комплексного використання традиційної промислової рослинної сировини - плодово-ягідної. Оскільки, за літературними даними, біологічно активні речовини накопичуються не тільки у частинах плодовоягідних дерев, які традиційно використовуються, а й у вегетативних - листях, бруньках, корі, гілочках та кісточках, їх екстракти можуть використовуватись для отримання препаратів біологічно активних речовин [13].

Косметичний догляд за шкірою складається із очищення, зволоження, тонізування, захисту i спеціального догляду.

Тонік косметичний - це косметичний засіб у вигляді водного розчину активнодіючих речовин (допустима об’ємна частка етилового спирту до 8\%), або рідкої емульсії, суспензії, який призначений для догляду за шкірою, волоссям, нігтями; виявляє тонізуючу дію, використовується для очищення, нормалізації кислотно-лужного балансу, підвищення тонусу шкіри, пружності та еластичності. Переважно тоніки застосовують для догляду за сухою, а також нормальною шкірою, оскільки вони не пересушують шкіру через відсутність спирту. Він класифікується як косметичний препарат, може містити ароматичні сполуки [14].

Тоніки також володіють лікарськими властивостями, вони містять антибіотики, антисептики, протигрибкові, анти-акне агенти, заспокійливі, зволожуючі та захисні засоби [15].

Мета дослідження - розробити екстракти з м'ятки ядра абрикосових кісточок, науково обгрунтовані рецептуру та технологію натурального косметичного тоніка на основі екстракту 3 м'ятки ядра абрикосових кісточок із найвищою біологічною активністю.

Завдання дослідження:

- розробити схему отримання водного, спиртового та водно-спиртового екстрактів 3 м'ятки ядра абрикосових кісточок;

- визначити біологічну активність екстрактів з м’ятки ядра абрикосових кісточок, отриманих за розробленою схемою;

- надати рекомендації щодо застосування екстракту з м'ятки ядра абрикосових кісточок 3 найвищою біологічною активністю у рецептурі та технології косметичного тоніка;

- розробити науково обгрунтовані рецептуру та технологію косметичного тоніка на основі екстракту 3 м'ятки ядра абрикосових кісточок;

- визначити показники якості косметичного тоніка на основі екстракту з м'ятки ядра абрикосових кісточок, виробленого за розробленою технологією, та встановити його вплив на стан шкіри респондентів-добровольців. 
Екстрактом прийнято називати витяжку лікарських речовин з рослин за допомогою розчинників (спирту, води, ефіру, гліцерину та їх сумішей). Найчастіше екстракт має високу концентрацію активних інгредієнтів та очищений від осаду. Відповідно до типу розчинника, екстракти бувають водні, спиртові, водно-спиртові та ефірні. На основі аналізу літературних даних була розроблена схема приготування водного екстракту з м’ятки ядра абрикосових кісточок, яка наведена на рис. 1.

Приготування водного екстракту 3 м'ятки ядра абрикосових кісточок складається 3 наступних технологічних операцій: підготовлену воду з ємності та м’ятку з бункера подають у змішувач, де перемішують протягом 20 хв. Перемішану масу насосом подають у ємність, де 24 години проходить настоювання водного екстракту за температури $20^{\circ} \mathrm{C}$. Після настоювання водний екстракт насосом подають на фільтр. Відфільтрований водний екстракт надходить в ємність для готового екстракту. Водний екстракт у подальшому використовують у виробництві косметичних засобів або фасують, пакують, маркують і відправляють на склад для зберігання.

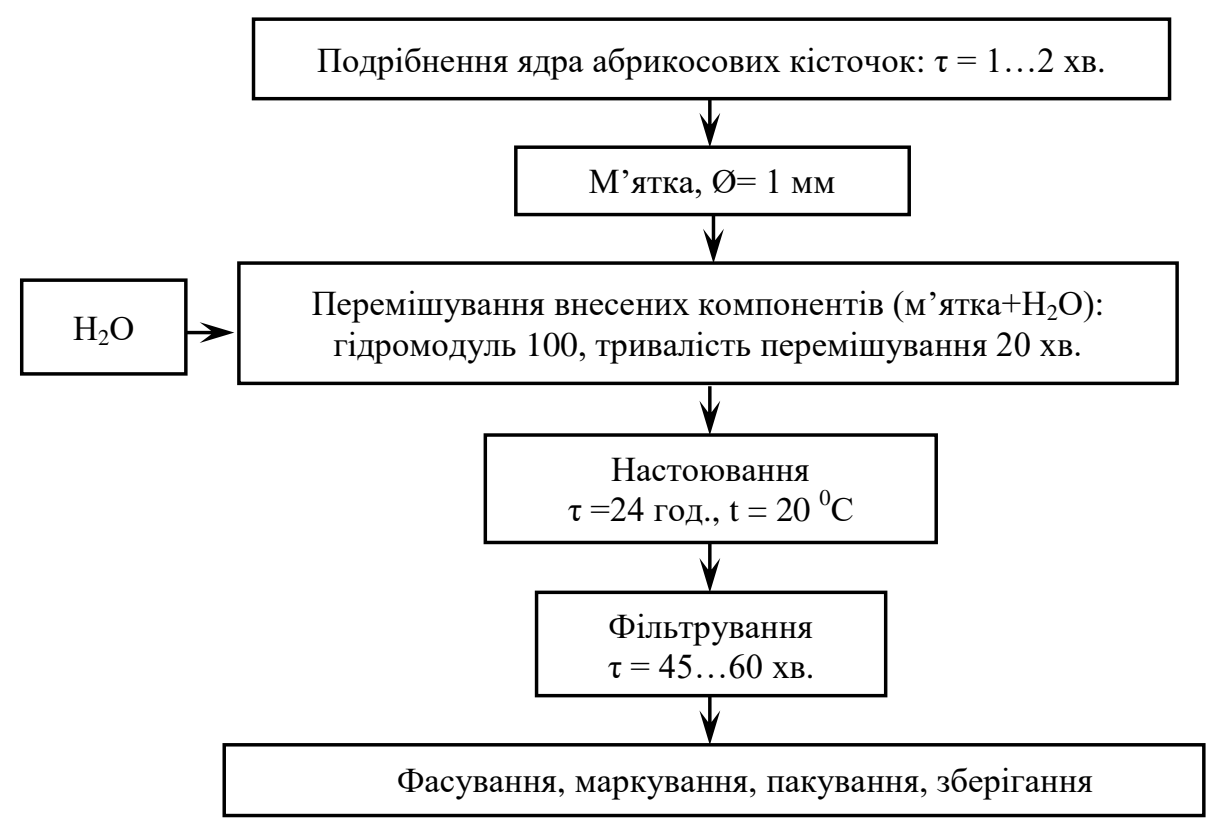

\section{Рис. 1. Векторна схема приготування водного екстракту з м'ятки ядра абрикосових кісточок}

За розробленою технологією (рис. 1) у лабораторних умовах кафедри технології молока, олійножирових продуктів та індустрії краси був отриманий водний екстракт із м'ятки ядра абрикосових кісточок. Аналогічним способом були приготовані спиртовий та водно-спиртовий екстракти 3 м'ятки ядра абрикосових кісточок (об’ємна частка спирту у водно-спиртовому екстракті склала 50 \%).

Наступним етапом стало визначення фізіологічного ефекту отриманих екстрактів за показником біологічної активності [17-18]. Даний показник широко використовують для аналізу харчових продуктів, які володіють оздоровчими, лікувальними або профілактичними властивостями [18-20]. При проведенні даного дослідження метою було довести, що розроблені водний, спиртовий та водно-спиртовий екстракти на основі м'ятки ядра абрикосових кісточок мають високу біологічну активність за рахунок високого вмісту в них антиоксидантів. Біологічна активність екстрактів з м'ятки ядра абрикосових кісточок преставлена на рис. 2.

Усі отримані в лабораторних умовах екстракти з м'ятки ядра абрикосових кісточок мають високу біологічну активність (рис. 2), оскільки швидкість перенесення електрона в системі $\mathrm{NAD} \cdot \mathrm{H}_{2}-\mathrm{K}_{3} \mathrm{Fe}(\mathrm{CN})_{6}$ суттєво збільшується у їх присутності, що свідчить про наявність антиоксидантної дії. Найвищу біологічну активність має водний екстракт - 130000 ум.од.акт., що на 23,8 та 8,3 \% перевищує аналогічний показник спиртового та водно-спитрового екстрактів відповідно (рис. 2). Тому для виробництва косметичного тоніка рекомендовано використовувати водний екстракт 3 м'ятки ядра абрикосових кісточок.

Тоніки відносять до рідких гомогенних косметичних засобів, які застосовують для додаткового очищення та тонізування шкіри згідно з ДСТУ 2472:2006 «Продукція парфумерно-косметична. Терміни та визначення понять», а також ДСТУ 4093-2002 «Лосьйони та тоніки косметичні» $[15,16]$.

Для розробки рецептури косметичного тоніка із застосуванням водного екстракту 3 м'ятки ядра абрикосових кісточок була використана базова рецептура тоніка за [21]. 


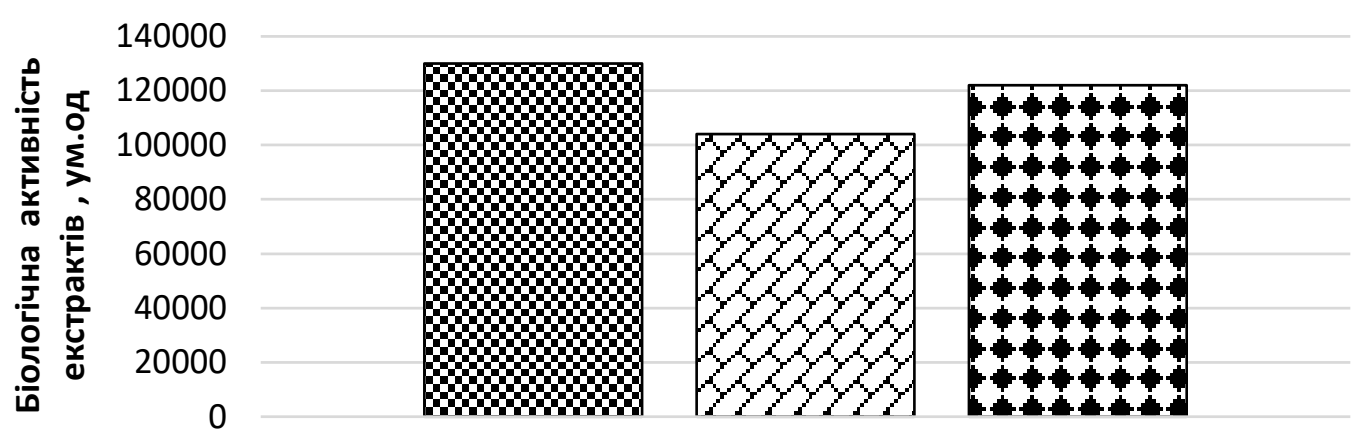

Екстракти

\section{ВВодний ФСпиртовий ШВодно-спиртовий}

\section{Рис. 2. Біологічна активність екстрактів з м'ятки ядра абрикосових кісточок}

У роботі було поставлено за мету розробити рецептуру та технологію натурального косметичного тоніка, тому від використання антисептиків у рецептурі цільового косметичного засобу відмовилися.

У базовій рецептурі 40 \% води питної було замінено на екстракт з м'ятки ядра абрикосових кісточок (масова частка екстракту у рецептурі натурального косметичного тоніка склала 38,3 \%). Запропонована рецептура натурального косметичного тоніка з водним екстрактом із м'ятки ядра абрикосових кісточок наведена в табл. 1.

Таблиця 1 - Рецептура натурального косметичного тоніка для шкіри обличчя на основі водного екстракту з м'ятки ядра абрикосових кісточок

\begin{tabular}{|l|c|}
\hline \multicolumn{1}{|c|}{ Назва компонента } & Маса компонента (кг на 100 кг тоніка) \\
Глюкоза & без врахування втрат \\
Лимонна кислота & 0,4 \\
Натрій хлорид & 0,2 \\
Гліцерин & 0,9 \\
Вода питна & 3,0 \\
Водний екстракт з м’ятки ядра абрикосових кісточок & 57,0 \\
Ефірна олія лимона & 38,3 \\
Всього: & 0,2 \\
\hline
\end{tabular}

При удосконаленні технологічної схеми виробництва натурального косметичного тоніка 3 водним екстрактом із м'ятки ядра абрикосових кісточок використовували існуючу технологію тоніків, наведену в [21]. Додатковими операціями при виробництві тоніка за розробленою рецептурою стануть ті, які пов'язані з отриманням водного екстракту із м'ятки ядра абрикосових кісточок за схемою, наведеною на рис. 1, якщо екстракт отримують безпосередньо на косметичному підприємстві. Якщо косметичне підприємство використовує готовий екстракт, удосконалена технологія виробництва натурального косметичного тоніка з водним екстрактом із м’ятки ядра абрикосових кісточок буде спрощеною; вона наведена на рис. 3.

У натуральному косметичному тоніку для шкіри обличчя, виготовленому на основі водного екстракту з м'ятки ядра абрикосових кісточок, були досліджені фізико-хімічні та біохімічні показники, а також сенсорні характеристики. Результати досліджень наведені у табл. 2.

Натуральний косметичний тонік для шкіри обличчя, виготовлений на основі водного екстракту 3 м'ятки ядра абрикосових кісточок, за сенсорними характеристиками та фізико-хімічними показниками відповідає вимогам ДСТУ [15] (табл. 2): він має стабільну консистенцію, приємний світло-жовтий колір і аромат ефірної олії; показник рН знаходиться у нормі (за [15] межі рН від 3,5 до 8,0). Крім того, розроблений косметичний засіб має високе значення біологічної активності - $(4980 \pm 20)$ ум.од.акт., що дає підстави прогнозувати його позитивний вплив на шкіру обличчя, зокрема, антиоксидантний захист шкіри.

Дію розробленого натурального косметичного тоніка було перевірено за участі 20 респодентівдобровольців (табл. 3). Усі вони відмітили приємний аромат продукту, значне пом'якшення шкіри 
обличчя після нанесення засобу (а респонденти із сухою шкірою - ще й зволоження шкіри), відчуття очищення та тонізування шкіри. У жодної людини тонік не викликав алергічних реакцій.

Таблиця 2 - Фізико-хімічні, біохімічні показники та сенсорні характеристики натурального косметичного тоніка для шкіри обличчя на основі водного екстракту з м'ятки ядра абрикосових кісточок

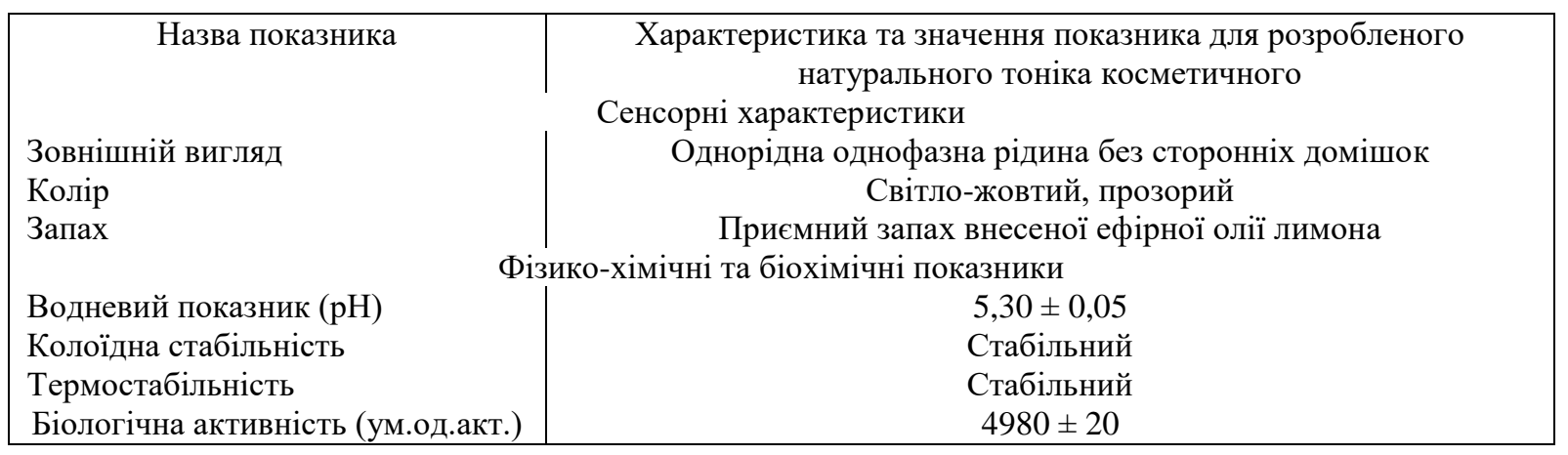

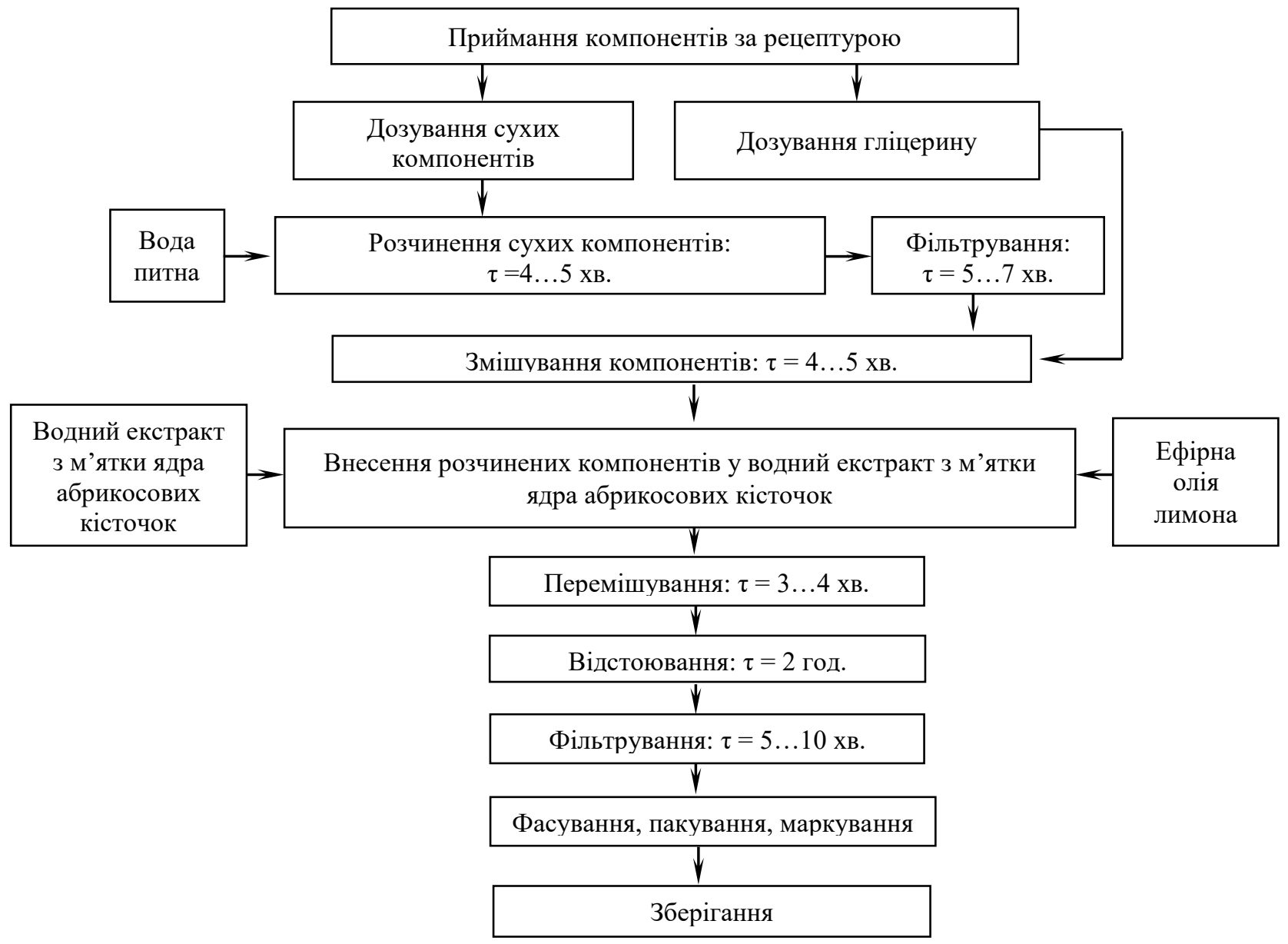

Рис. 3. Удосконалена схема приготування натурального косметичного тоніка для шкіри обличчя на основі водного екстракту з м'ятки ядра абрикосових кісточок

На основі отриманих результатів можна рекомендувати проведення клінічних досліджень щодо впливу розробленого натурального косметичного тоніка на шкіру обличчя різних типів на базі Одеського національного медичного університету.

Наступним етапом дослідження стало визначення мікробіологічної безпечності натурального косметичного тоніка для обличчя, виготовленого на основі водного екстракту з м'ятки ядра абрикосових кісточок. Тонік зберігали за кімнатної температури - $(20 \pm 1){ }^{\circ} \mathrm{C}$ протягом 35 діб. Через кожні 5 діб у виробленому тоніку визначали КМАФАнМ. Результати досліджень наведені на рис. 4. 
Таблиця 3 - Вплив натурального косметичного тоніка для шкіри обличчя на основі водного екстракту з м'ятки ядра абрикосових кісточок на шкіру респондентів-добровольців

Дані респондентів-добровольців

Група 1: жіноча, вік $20 . .30$ років 3 жирним типом шкіри - 10 респондентів

Група 2: жіноча, вік $30 . .50$ років з сухим типом шкіри -5 респондентів

Група 3: чоловіча, вік $30 . .50$ років з сухим типом шкіри -5 респондентів
Характеристика та значення показника для розробленого натурального тоніка косметичного

Значне пом'якшення шкіри обличчя після нанесення засобу, відчуття очищення та тонізування шкіри

Значне пом'якшення та зволоження шкіри обличчя після нанесення засобу, відчуття очищення та тонізування шкіри

Значне пом'якшення та зволоження шкіри обличчя після нанесення засобу, відчуття очищення та тонізування шкіри

Результати проведених досліджень свідчать, що КМАФАнМ у натуральному косметичному тоніку для обличчя відповідають вимогам нормативної документації протягом 30 діб, на 35 добу зберігання цей

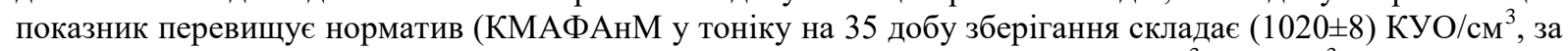
вимогами НД КМАФАнМ у цільовому продукті не повинно перевищувати $1 \times 10^{3}$ КУО/см ${ }^{3}$.

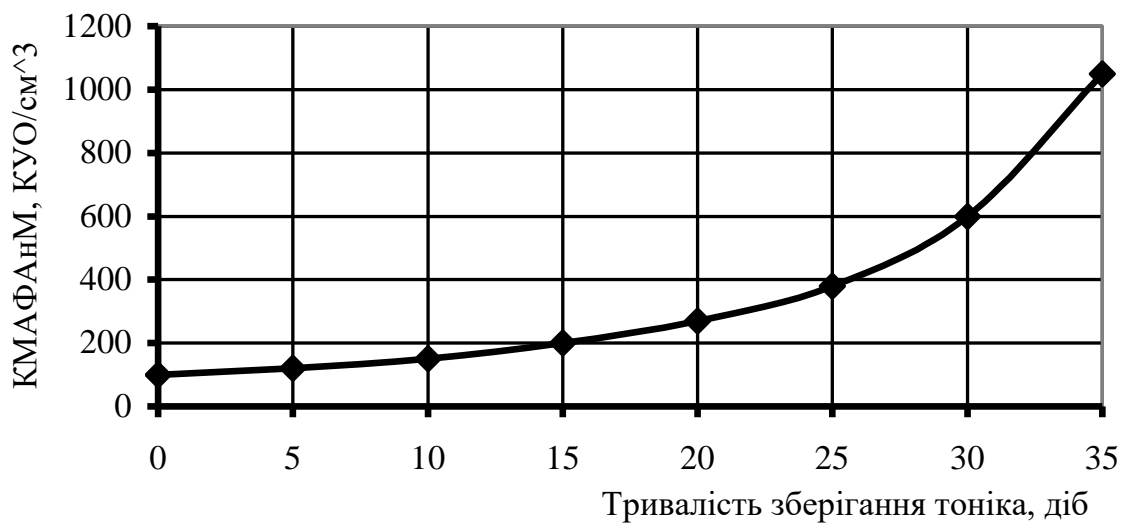

Рис. 4 - Зміна КМАФАнМ у натуральному косметичному тоніку для шкіри обличчя на основі водного екстракту 3 м'ятки ядра абрикосових кісточок

На основі проведених мікробіологічних досліджень можна зробити висновок про термін придатності косметичного тоніка. Максимальний термін зберігання натурального косметичного тоніка за кімнатної температури $-(20 \pm 1){ }^{\circ} \mathrm{C}$ не повинен перевищувати 30 діб. Після 30 діб збрігання використовувати даний косметичний продукт не рекомендовано.

\section{Висновки}

1. На основі літературних даних, які свідчать про доцільність використання екстрактів 3 м'ятки ядра абрикосових кісточок у косметичних продуктах, а саме тоніках, та результатів проведених експериментальних досліджень розроблена рецептура i удосконалена технологія виробництва натурального косметичного тоніка для шкіри обличчя на основі водного екстракту 3 м’ятки ядра абрикосових кісточок.

2. Запропонована технологічна схема отримання водного, спиртового та водно-спиртового екстрактів із м'ятки ядра абрикосових кісточок. Отримані за цією технологією екстракти на основі м'ятки ядра абрикосових кісточок мають високу біологічну активність, що обумовлено наявністю у іх складі водорозчинних біологічно-активних речовин, які володіють антиоксидантними властивостями. Дослідження біологічної активності водного, спиртового та водно-спиртового екстрактів на основі м'ятки ядра абрикосових кісточок свідчать, що водний екстракт характеризується найвищим значенням даного показника, тому саме на його основі розроблена рецептура та удосконалена технологічна схема косметичного тоніка для шкіри обличчя.

3. Вироблений за розробленою технологією натуральний косметичний тонік відповідає вимогам ДСТУ 4093-2002. Він має стабільну структуру, приємний колір та аромат ефірної олії. Показник $\mathrm{pH}$ знаходиться у нормі (межі - від 3,5 до 8,0).

4. Встановлено, що натуральний косметичний тонік для обличчя на основі водного екстракту 3 м'ятки абрикосового ядра біологічно активний, оскільки швидкість перенесення електрона в системі $\mathrm{NAD} \cdot \mathrm{H}_{2}-\mathrm{K}_{3} \mathrm{Fe}(\mathrm{CN})_{6}$ збільшується у його присутності. 
5. Дію розробленого натурального косметичного тоніка було перевірено за участі 20 респодентівдобровольців. Усі вони відмітили приємний аромат продукту, значне пом'якшення шкіри обличчя після нанесення засобу (а респонденти із сухою шкірою - ще й зволоження шкіри), відчуття очищення та тонізування шкіри. У жодної людини тонік не викликав алергічних реакцій.

6. Встановлено максимальний термін зберігання розробленого тоніка 30 діб за температури $(20 \pm 1)^{\circ} \mathrm{C}$.

\section{References}

1. Ferreira, S., Caliari, M., Soares Júnior, M., Del Pino Beleia, A. (2014). Infant dairy-cereal mixture for the preparation of a gluten free cream using enzymatically modified rice flour. LWT - Food Science And Technology. 59(2). 1033 - 1040. https://doi.org/10.1016/j.lwt.2014.06.047

2. Coman, M., Verdenelli, M., Cecchini, C., Silvi, S., Vasile, A., Bahrim, G.E., Orpianesi, C., Cresci, A. (2013). Effect of buckwheat flour and oat bran on growth and cell viability of the probiotic strains Lactobacillus rhamnosus IMC 501®, Lactobacillus paracasei IMC 502® and their combination SYNBIO ${ }^{\circledR}$, in synbiotic fermented milk. International Journal Of Food Microbiology. 167(2). 261 268. https://doi.org/10.1016/j.ijfoodmicro.2013.09.015

3. Sedarnawati, Y., Ayuni, M. (2014). Development of corn milk yoghurt using mixed culture of Lactobacillus delbruekii, Streptococcus salivarus, and Lactobacillus casei. HAYATI Journal of Biosciences. 21(1). 1 7. https://doi.org/10.4308/hjb.21.1.1

4. Zare, F., Champagne, C.P., Simpson, B.K., Orsat, V., Boye, J.I. (2012). Effect of the addition of pulse ingredients to milk on acid production by probiotic and yoghurt starter cultures. LWT - Food Science And Technology. 45(2). 155 - 160. https://doi.org/10.1016/j.lwt.2011.08.012

5. Casarotti, S., Penna, A. (2015). Acidification profile, probiotic in vitro gastrointestinal tolerance and viability in fermented milk with fruit flours. International Dairy Journal. 41.1 - 6. https://doi.org/10.1016/j.idairyj.2014.08.021

6. Dal Bello, B., Torri, L., Piochi, M., Zeppa, G. (2015). Healthy yogurt fortified with n-3 fatty acids from vegetable sources. Journal of Dairy Science. 98(12). 8375 - 8385. https://doi.org/10.3168/jds.2015$\underline{9688}$

7. Rudakova, T.V. (2015). Tekhnolohiya vyrobiv syrkovykh dlya dytyachoho kharchuvannya z vykorystannyam produktiv pererobky zerna. Zernovi produkty i kombikormy. 2(58). 9 - 14.

8. Anikina, E.N., Pas'ko, O.V., Konovalov, S.A. (2013). Proektirovanie retseptury i razrabotka tekhnologii bioprodukta s ovsyanym toloknom. Agrarnyy vestnik Urala. 5(111). 26 - 29.

9. Gavrilova, N.B. (2004). Biotehnologija kombinirovannyh molochnyh produktov. Monografija. Omsk: «Variant-Sibir'». 224. ISBN 5-7065-0243-9.

10. Anikina, E.N., Pas'ko, O.V., Konovalov, S.A. (2013). Proektirovanie receptury i razrabotka tehnologii bioprodukta s ovsjanym toloknom . Agrarnyj vestnik Urala.. № 5 (111). 26-29.

11. Kalinina, L.V., Ganina, V.I., Dunchenko N.I. (2008). Tehnologija cel'nomolochnyh produktov. SPb.: GIORD, 248.

12. Skorchenko, T.A., Polishchuk, G.C., Grek, O.V., Kochubei, O.V. (2005). Tekhnologiia nezbiranomolochnikh produktiv. Vinnitcia: Nova Kniga. 264.

13. Tikhomirova, N.A. (2007). Tekhnologiia i organizatciia proizvodstva moloka i molochnykh produktov. M.: DeLi print. 560.

14. Gurova, N.V. i dr. (2001). Funktcionalnye svoistva gidrokolloidov // Uchebno-metodicheskoe posobie «Khimiia pishchevykh gidrokolloidov». 12-34.

15. Tkachenko, N.A., Nekrasov, P.O., Kopijko, A.V. (2016). Matematy`chne modelyuvannya komponentnogo skladu kombinovany`x jogurtovy`x napoyiv. Zernovi produkty`i kombikormy`, 1. 20-25.

16. Krus, G.N., Khramtcov, A.G., Volokitina, E.V., Karpychev, S.V. (2006). Tekhnologiia moloka i molochnykh produktov. Moskva: Kolos. 455.

Cite as

Котляр Є.О., Ткаченко Н.А., Вікуль С.І., Левчук І.В. Технологія натурального косметичного тоніка на основі водного екстракту з м'ятки ядра абрикосових кісточок // Наук. пр. / Одес. нац. акад. харч. технологій. Одеса, 2020. Т. 84, вип. 2. С. $30-37$.

Отримано в редакцію 07.07.2020

Прийнято до друку 22.09 .2020
Received 07.07.2020

Approved 22.09.2020 